\title{
DIGITAL MANUFACTURING: NEW CHALLENGES FOR MARKETING AND BUSINESS MODELS
}

\author{
A.O. DAVIY* \\ National Research University Higher School of Economics at St. Petersburg, \\ Russia ${ }^{\mathrm{a}}$
}

S. N. PAKLINA

National Research University Higher School of Economics at Perm, Russia ${ }^{\text {b }}$

\author{
A. S. PROKOFYEVA \\ Galaktika GK, Russia ${ }^{\mathrm{c}}$
}

\begin{abstract}
This paper is aimed at identifying the role of digital manufacturing in changes of marketing activities of industrial companies from the point of view of a business management system. Authors define and conceptualize the notion of "digital manufacturing". Research design is based on the Deloitte Company methodology based on value creation approach. Customers, product, economics of production, and value chain are essential methodology parameters. Our analysis shows that implementation of digital manufacturing will necessarily significantly change entire business model and marketing activity of the company. The main drivers of this process are building and maintaining relationship with customers and new opportunities related to product design and production. Interaction with customers without intermediaries, customers' involvement in the processes of new products development, new technical possibilities of creating personalized product-service solution are main changes in marketing activities caused by the implementation of digital manufacturing at the company.
\end{abstract}

Keywords: digital manufacturing, marketing, business model.

JEL: M31.

The publication was prepared within the framework of the Academic Fund Program at the National Research University Higher School of Economics (HSE) in 2016-2017 (grant № 16-01-0079) and by the Russian Academic Excellence Project "5-100".

* Corresponding author: adaviy@hse.ru

${ }^{a}$ Postal Address: 3 Kantemirovskaya ul., National Research University Higher School of Economics at Saint Petersburg, St. Petersburg, 194100, Russia.

${ }^{b}$ Postal Address: 38 Studencheskaya ul., National Research University Higher School of Economics at Perm, Perm, 614070, Russia.

c Postal Address: 12 3-ya Khoroshevskaya ul., Galaktika GK, Moscow, Russia.

(C) A. O. Daviy, S. N.Paklina, A.S. Prokofyeva, 2017

https://doi.org/10.21638/11701/spbu18.2017.408 


\section{Introduction}

We may be witnessing the next step in a revolution in production, moving from the knowledge economy, which has lasted for at least two decades, to the new digital era. To understand how the megatrends of cloud, mobile, social, and big data are affecting businesses, Microsoft sponsored the study "The Digital Transformation of Business", conducted by Harvard Business Review Analytic Services [The Digital..., 2015]. The survey, polling 537 executives of enterprise organizations, provides surprising insights into the transformative effects of technology on business operations. The survey finds that firms are embracing the digital transformation process to craft new business models, develop new revenue streams, or drive other material changes that lead to an increase in the top or bottom lines. Thus, simply spending more on emerging technologies is not enough to boost business outcomes. Instead, companies that both identify, which core business capabilities they need to differentiate, and make a commitment to transform these core business capabilities with the right digital technology will greatly outperform competitors who do not follow this approach.

As [Rashid, 2017] notes, digital transformation is not just about embracing new technology; it is about a change in thought and organization culture. There is a need for organizations to address the change in business scenarios and dynamic business demands and to innovate ways to quickly cater to these changing needs. Thus, digital transformation is about accelerating business activities, lowering costs, improving time to market, and bringing about a positive change in processes, people, and competency models.

Policy makers both in business and public sector recognize that emerging digital trends might significantly change a basis of any economy that lies in production. These trends are to transform principal technologies and impact on business models It has to be noted that in many industries digi- talization turns to be not just a source of productivity growth but moreover provide an important innovation process [Grieves, 2015; Spelman et al., 2016]. Furthermore, digitalization drives the most substantial radical innovations both technological and managerial. That has an evident impact on the value chain and bears several corporate risks. Despite the strategic shift towards digitalization there is a bunch of companies that still resists on transformation [Baur, Wee, 2015; Spelman et al., 2016].

The rapidly growing importance of digitalization is attracting excessive attention of scholars. One of the most topical research questions refers to the production digitalization or digital manufacturing (DM). This problem is discussed in papers by [DaltonTaggart, 2005; Chryssolouris et al., 2009; Zhou, Xie, Chen, 2011; Chen et al., 2015; Khajavi et al., 2015]. Digitalization is a kind of a very broad concept. The conventional meaning of the digitalization process refers to the transformation from the analog principals to the digital ones [Digitalization Trends and Solutions..., 2015]. However, there are more very important markers of digitalization: automatization, data management, and digital communications, reengineering of business processes, humancomputer interactions and data flows [Digitalization - Trends and Solutions..., 2015; Digitalization..., 2015]. An active use of digital technologies and solutions leads to the overall transformation of manufacturing. According to the studies like those by $\left[\mathrm{Ku}^{-}\right.$ ehn, 2006; Lay, 2014; Macaulay et al., 2015; Gerbert et al., 2015; Wee et al., 2015] digital manufacturing will become a hygienic norm in the nearest future having a great potential to change every important business process around. Digital manufacturing is seen in the literature as a radical transformation of the entire business. The focus on the marketing issues of this paper still implies it integrative role for the company in general.

According to the scientometric statistics the majority of papers on digital manufacturing are considered in specific domains of 
engineering and computer sciences. Meanwhile the recent growing trend refers to business studies likewise.

While this research field is on the early stage of formation, we can find an evident popularity of digital transformation in marketing studies and practices. That may be seen the most interesting and perspective research line that penetrates in all possible business spheres: customization [Hu, 2013; Chen et al., 2015], customer loyalty and trust, networking [Geissbauer, Vedso, Schrauf, 2016] and many other. The issues of business models have received a crucial attention. Since digital manufacturing dramatically impacts the part of the value chain focused on value creation and value delivery, producers have had the opportunity to produce customized goods to meet individual consumers' need. It requires to increase level of engagement and synchronization of all participants of this value chain but on the contrary results in an on-demand production and better visualization and understanding value stream. Generally, this ongoing shift from producer-centric to consumercentric value chain will continue to challenge the manufacturers and lead to further transformation of business model.

Despite a clear interest of scholars to digital business trends there are still no integral studies on this issue, especially theoretical ones. Alongside, from practical perspective this phenomenon is also investigated only in some pilot studies conducted by consulting companies, for example, [The Digital..., 2015; Geissbauer, Vedso, Schrauf, 2016]. Since these investigations try to describe this emerging research topic they are major area of interest within the field, but generally the current papers cover just certain fragments of the problem not considering them in cohesion with each other. In trying to fill in this gap our paper aims at conceptualization and problematization of the digital transformation of marketing due to digital manufacturing. We would seek to discover and explore the main trends of marketing that serves digital transformation of the industry. We will look at digital manufacturing and technologies that accompany this transformation from the all-important prospective. As we expect the major issue appears to be a business model that makes a company a coherent system.

The remainder of the paper consists of the three major parts. The first section sheds some light on the evolution of manufacturing trends that led to digital transformation. The second part demonstrates methodological framework of this study. The main conceptual findings conclude this paper in the third section.

\section{Definition and conceptualization of digital manufacturing}

As an area digital manufacturing is currently attracting considerable interest from researchers and companies, however as a research field it is still in the stage of formation [Zhou, Xie, Chen, 2011]. The topic is developing quite rapidly, but till now there is no consensus on a definition of digital manufacturing among researchers and business representatives. Table 1 highlights these various approaches to defining digital manufacturing.

As the table shows, variety of approaches to the definition of digital manufacturing confirm the statement that there is no common opinion among researchers and practitioners what is digital manufacturing and how it should be understood. However, this theoretical analysis allows to highlight the essential characteristics of the term:

- DM is a complex of various information and computer technology and special equipment, e.g., sensors, 3D printers, robots, etc.

- DM, integrated with the physical plant production, allows companies to plan and manage a product lifecycle and production capacity digitally [Bloem et al., 2014].

- Input of DM is large number of data, output - smart product and in some cases a comprehensive proposal that combines a product and related services. 


\section{Definition of digital manufacturing proposed by researchers and business representatives}

\begin{tabular}{|c|c|}
\hline Paper & \\
\hline $\begin{array}{l}\text { Tanufac- } \\
\text { uring..., } \\
011]\end{array}$ & $\begin{array}{l}\text { gital manufacturing as systems that support the definition of processes used to produce } \\
\text { product, including supporting simulation and analysis of those processes, and the manu- } \\
\text { cturing environments used to produce the product, including production equipment and } \\
\text { hes }\end{array}$ \\
\hline 005] & $\begin{array}{l}\text { gital Manufacturing is an approach involving people, process/practice, and technol- } \\
\text { y that uses PLM information to plan, engineer, and build the first instance of a prod- } \\
\text { t; ramp that product up for volume production; and produce, monitor, and capture for } \\
\text { her aspects of the lifecycle the remaining instances of that product's production using } \\
\text { e minimum amount of resources possible }\end{array}$ \\
\hline $\begin{array}{l}\text { Digital } \\
\text { Manufac- } \\
\text { uring, } \\
\text { 2015a] }\end{array}$ & $\begin{array}{l}\text { gital manufacturing means using new technologies like data analytics, the cloud and } \\
\text { e Internet of Things to merge the virtual and real worlds. This enables manufactur- } \\
\text { s to increase productivity across their entire value chain, from design and engineering } \\
\text { sales, production and service. In concrete terms, this means faster time-to-market, } \\
\text { eater flexibility and enhanced availability of systems on the plant floor }\end{array}$ \\
\hline $\begin{array}{l}\text { Manufac- } \\
\text { uring, } \\
\text { 015b] }\end{array}$ & $\begin{array}{l}\text { gital manufacturing meant a series of processes capable of encompassing the entire } \\
\text { anufacturing lifecycle, from the earliest product design work using virtual modeling, } \\
\text { ototyping and simulation, to automated manufacturing and assembly, and even to field } \\
\text { rvice }\end{array}$ \\
\hline Robinson, & gital manufacturing is the us \\
\hline $\begin{array}{l}\text { [Dalton- } \\
\text { Taggart, } \\
\text { 2005] }\end{array}$ & ystems, analy- \\
\hline $\begin{array}{l}\text { [Westkäm- } \\
\text { per, 2007] }\end{array}$ & $\begin{array}{l}\text { ata management } \\
\text { manufacturing before }\end{array}$ \\
\hline Shrysso- & $\begin{array}{l}\text { Digital manufacturing incorporates technologies for the virtual representation of factories, } \\
\text { buildings, resources, machine systems equipment, labour staff and their skills, as well as for } \\
\text { the closer integration of product and process development through modeling and simulation }\end{array}$ \\
\hline [Abrell et & $\begin{array}{l}\text { Digital manufacturing is concept where digital technologies such as sensors, RFID tags, } \\
\text { and cloud computing can be embedded into non-digital products and services to produce } \\
\text { networked "smart factories" with flexible and adaptive production processes }\end{array}$ \\
\hline
\end{tabular}

- DM allows to visualize all processes occurring in the production, for its subsequent optimization and control.

- DM can change all processes of manufacturing production.

In this paper the concept of digital manufacturing is defined as a set of technological solutions, systems and technical devices providing partial or full automation and autonomy of production processes.

Overall, digital manufacturing as a complex of technologies has appeared recently, however, technology itself, constituting its essence, have been actively developing during the last $20-30$ years. Table 2 presents the basic technology providing digital manufacturing.

As can be seen from table 2 the digital manufacturing includes four main technological components. At the conceptual level it's proposed that company employing DM should apply an integrated approach to the production processes development and use all technologies listed above simultaneously. 
Table 2

Key technological components of digital manufacturing

\begin{tabular}{|c|c|c|}
\hline $\begin{array}{l}\text { Technological } \\
\text { components }\end{array}$ & Essence of technology & Practical implementation \\
\hline $\begin{array}{l}\text { Computer- } \\
\text { aided tech- } \\
\text { nologies }\end{array}$ & $\begin{array}{l}\text { Functionalities of such systems inte- } \\
\text { grate finite element analysis (FEA), } \\
\text { kinematics analysis, dynamic analysis } \\
\text { and full simulation of geometrical prop- } \\
\text { erties including texture and mechanical } \\
\text { properties of materials }\end{array}$ & $\begin{array}{l}\text { Computer-aided process planning (CAPP) sys- } \\
\text { tems. } \\
\text { Computer-aided engineering (CAE) systems. } \\
\text { Computer-aided manufacturing (CAM) systems. } \\
\text { Computer numerical control (CNC). } \\
\text { Product data management (PDM) systems. } \\
\text { Product life-cycle management (PLM) systems }\end{array}$ \\
\hline $\begin{array}{l}\text { Manufac- } \\
\text { turing } \\
\text { control }\end{array}$ & $\begin{array}{l}\text { Scheduling systems for real-time control } \\
\text { based on the distributed networking } \\
\text { between sensors and control devices }\end{array}$ & $\begin{array}{l}\text { Automated identification systems, including: } \\
\text { - radiofrequency identification (RFID); } \\
\text { - global system for mobile communications } \\
\text { (GSM) }\end{array}$ \\
\hline Simulation & $\begin{array}{l}\text { Study and statistical analyses what-if } \\
\text { scenarios }\end{array}$ & $\begin{array}{l}\text { Digital mock-up (DMU) software. } \\
\text { Discrete event simulation (DES) software. } \\
\text { 3D simulation. } \\
\text { An extension to simulation technology (the vir- } \\
\quad \text { tual reality (VR) technology) }\end{array}$ \\
\hline $\begin{array}{l}\text { Enterprise } \\
\text { resource } \\
\text { planning and } \\
\text { optimization }\end{array}$ & $\begin{array}{l}\text { All data and processes of an organiza- } \\
\text { tion are integrated into a unified sys- } \\
\text { tem. Obtained and analyzed information } \\
\text { allow to reveal changes in manufactur- } \\
\text { ing processes and plan resources }\end{array}$ & $\begin{array}{l}\text { Enterprise resource planning (ERP) systems. } \\
\text { Manufacturing resources planning (MRP II) } \\
\text { systems }\end{array}$ \\
\hline
\end{tabular}

Adapted from: [Chryssolouris et al., 2009; Digital Manufacturing, 2011].

In practice, however, a factory or plant may use only one or several technological components but not all. It should be noted that the implementation of digital manufacturing even at the level of a single component can lead to some noticeable results. For example, computer technology in the product design stage allows engineer-technologist to compare the ability of current equipment with technical characteristics inherent in a product model. While computer systems have some limitations, they can find out the best permutations and combinations of hardware, which enable not only to produce required goods, but do it with minimal time, resources and energy cost [Grieves, 2005]. As technologies forming digital manufacturing can be easily integrated, later the company may extend the implementation of DM through adding new technologies to the already embedded ones [Digital Manufacturing, 2011]. On the one side, the usage of a new set of technologies will increase the companies' efficiency on the certain manufacturing process, on the other side, the synergy effect from the use of complex technological solutions will appear.

In general, pooling different functional systems provides digital manufacturing significant advantages over the traditional form of production process. Table 3 includes the most significant business results that can be achieved from the DM employing.

As table 3 shows, researchers and business representatives identify a significantly large number of benefits of digital manufacturing implementation in practice. According to the table, most common advantages are increased profitability of production, time reduction in production and delivery products to the consumer, deeper knowledge integration and its effective management. To date, several pilot studies were conducted (see CIMdata Research in [Grieves, 2005]; SCM World/Cisco survey in [Boosting Visibility, Agility..., 2015]), that studies 
Benefits of digital manufacturing

\begin{tabular}{|c|c|}
\hline Group of benefits & Benefits of digital manufacturing \\
\hline Value Drivers & $\begin{array}{l}\text { Increase equipment lifespan. } \\
\text { Reduce maintenance costs. } \\
\text { Reduce cabling costs. } \\
\text { Reduce provisioning, clearance, idle times. } \\
\text { Reduce time to process orders. } \\
\text { Increase production volumes }\end{array}$ \\
\hline Employee Productivity & $\begin{array}{l}\text { Train efficiently with collaboration solutions. } \\
\text { Automate your workforce management. } \\
\text { Increase worker mobility. } \\
\text { High-quality knowledge management }\end{array}$ \\
\hline Sustainability & $\begin{array}{l}\text { Reduce energy consumption. } \\
\text { Improve quality. } \\
\text { Improve capacity management. } \\
\text { Increase operational efficiency. } \\
\text { Reduce rework and scrap. } \\
\text { Early validation of manufacturing processes. } \\
\text { Improve quality of planning, standardization in planning. } \\
\text { Build more effective work with partners based on the highly productive infor- } \\
\quad \text { mation platforms. } \\
\text { Single data integration system }\end{array}$ \\
\hline Innovation & $\begin{array}{l}\text { Accelerate time to market. } \\
\text { Integrate real-time customer feedback. } \\
\text { Analyze remote product performance }\end{array}$ \\
\hline $\begin{array}{l}\text { Supply Chain \& } \\
\text { Logistics }\end{array}$ & $\begin{array}{l}\text { Reduce accidents. } \\
\text { Reduce loss and theft }\end{array}$ \\
\hline Customer Experience & $\begin{array}{l}\text { Improve accuracy of warranty modeling. } \\
\text { Customize production output }\end{array}$ \\
\hline
\end{tabular}

Sources: [Boosting Visibility, Agility..., 2015; Chryssolouris et al., 2009; Kuehn, 2006; Macaulay et al., 2015; Miller, MacKrell, 2007].

demonstrates the first attempts to measure quantitative results from DM implementation. The results of both studies are rather impressive. So, for example, Cisco notes (SCM World/Cisco survey in [Boosting Visibility, Agility..., 2015]) that companies using DM decrease reject rate by $48,9 \%$, downtime is by $47,8 \%$, time of new product launch by $23 \%$.

According to [Macaulay et al., 2015], advantages indicated in table 3 can ensure the profitability of the company roughly for 10 years. On the contrary, companies that will not learn how to use digital technologies, unable to compete and will be forced to leave the market. The number of such companies in various industries in the next five years can be up to $40 \%$ [Namboodri, 2015]. Therefore, CEO have realized that full or partial implementation of the DM enables companies not only to maintain its place in the market, but also to occupy a leading position in the future.

Generally, forward-thinking manufacturers perceive changes that digital technologies cause not as a new threat but also as a huge opportunity. Digital manufacturing will reconstruct manufacturing operations and all processes in the company - from R\&D and engineering to supply chain and services, that, finally, modify companies' business model. Next section of this study is dedicated to the changes that occur in the business models under the DM implementation, 
and the potential that digital manufacturing opens in front of businesses within their marketing activities.

\section{Changes in marketing activity of manufacturing companies occurring under digital manufacturing}

In traditional viewpoint an industrial company considers the product as the sole and main source of generating profit. Production of large quantities of homogeneous products was a guarantee of company's success in the market [Hagel et al., 2015]. According to consulting company Deloitte (see [Hagel et al., 2015]), technological changes in the industrial sector, and the growing digitalization of manufacturing companies devaluate previous factors of success and force companies to restructure their activities in line with the new realities of the market. In other words, in search of new competitive advantages, companies have to realign their business model (BM), paying considerable attention to the marketing component. Even though at the moment there is no clear definition of the business model, some researchers defining $\mathrm{BM}$ highlight the process of value creation as one of the key elements of BM [Zott, Amit, Massa, 2011]. Digital manufacturing creates a new production environment for the company and at the same time questions the traditional sources of value creation in production by revising and expanding them.

Deloitte has developed its own methodology for the assessment of changes in the manufacturing industry [Hagel et al., 2015]. The company proposes to analyze the changes and evaluate the impact of digital technologies on the production process, in four aspects: consumer, product, economy of production and value chains. It is important to note that these aspects are united by a single process - the process of value creation and value capture.

The advantage of this methodology is that allows researches and practitioners to consider changes taking place in manufacturing, under marketing focus because all compo- nents of the model related to the marketing. However, the marketing focus of this methodology is embedded in the broader context of value creation. Practically it enables to carry out the required analysis simultaneously with the marketing and business model's perspectives. Thus, this approach will be used to analyze the impact of digital production on the companies' business model and its marketing activity.

\section{Development of business models of manufacturing companies}

One of the major advantages of modern digital technologies lies in the opportunities for companies to manufacture customized products, communicate with customers through digital space and utilize technologies of direct production in order to lower costs, simplify supply chain and accelerate the process of filling orders. Thereby utilizing technologies that underlie digital manufacturing leads to significant changes concerning processes of production and delivery of products and as a result transforms traditional business models of manufacturing companies [Bogers, Hadar, Bilberg, 2016; Rayna, Striukova, 2016; Afuah, 2015; Amit, Zott, 2001; Schwab, 2016]. In general, implementation of digital manufacturing in company's activity can change all elements of its business model - value offer, value creation, value delivery and value capture [Rayna, Striukova, 2016]; however, technologies are more likely to influence offering and creating value.

Digital technologies offer opportunities for company to improve its product offering and influence its value offer [Rayna, Striukova, 2016]. Improvement of product offering becomes possible due to potential differentiation that producers can offer their customers. In particular, 3D printing can be used to create customized products or produce small batch. Besides, producers who have sufficient expertise in employment of 3D printing technology can offer their customers additional services, for instance, consulting about specificity of materials for $3 \mathrm{D}$ printers or providing guidelines for creating 
Table 4

Comparison of manufacturer-centric and consumer-centric business models

\begin{tabular}{l|l|l}
\hline \multicolumn{1}{c|}{ Characteristic } & \multicolumn{1}{|c}{ Manufacturer-centric } & \multicolumn{1}{c}{ Consumer-centric } \\
\hline Efficiency & $\begin{array}{l}\text { Process transparency. } \\
\text { Economies of scale. } \\
\text { Quality monitoring }\end{array}$ & $\begin{array}{l}\text { Low inventory cost. } \\
\text { Print on demand. } \\
\text { Low operating cost. } \\
\text { Model reuse }\end{array}$ \\
\hline Complementarities & $\begin{array}{l}\text { Portfolio-centric product development. } \\
\text { Designer creativity }\end{array}$ & $\begin{array}{l}\text { Indirect linkage to portfolio and product } \\
\text { designers. } \\
\text { Multi-partner platforms }\end{array}$ \\
\hline Nock-in & $\begin{array}{l}\text { Direct relation to product portfolio. } \\
\text { Company-centric community and shar- } \\
\text { ing }\end{array}$ & $\begin{array}{l}\text { Support in creation and printing. } \\
\text { Availability of platforms. } \\
\text { Community-driven sharing }\end{array}$ \\
\hline $\begin{array}{l}\text { Freedom for designers. } \\
\text { Unique design for special editions. } \\
\text { Co-creation optional }\end{array}$ & $\begin{array}{l}\text { Co-creation central to design. } \\
\text { Personalized designs. } \\
\text { Localized markets. } \\
\text { Optional subscription }\end{array}$ \\
\hline
\end{tabular}

S o u r c e: [Bogers, Hadar, Bilberg, 2016].

graphic models for further printing by utilizing additive technology [Bogers, Hadar, Bilberg, 2016].

Another aspect of value offer is that technologies of digital manufacturing provide companies with new opportunities to collect, use and dissemination of data. Manufacturing companies generates huge amount of information; however, they use only a small part of it. New methods of data processing allow companies collecting such data and increasing their competitiveness and attractiveness to customers through accelerating innovations, creating customized products and improving the overall efficiency of a company. In this context data becomes an asset of the company that can be used for its value creation [Kelly, 2015]. This approach can be illustrated by example of General Electric (GE) activity. In an interview, a company representative noticed that implementation of digital technologies encourages GE to rethink manufacturing process and design customization according the individual requirements. After changing the way of working with data, GE started to understand in detail how each element and component is produced starting from design phase to writing-off [Kelly, 2015].

Implementation of digital manufacturing into companies encourages changing the ap- proach to production: from creating manufacturer-centric value towards consumercentric value [Johnson, Christensen, Kagermann, 2008; Chesbrough, 2010; Bogers, Hadar, Bilberg, 2016]. Business models that focus on customers imply greater involvement of end consumer in production and other activities concerned with value creation. Based on sources of value creation proposed by [Amit, Zott, 2001; Bogers, Hadar, Bilberg, 2016] compare the logic of value creation within consumer-centric and manufacturercentric business models (table 4). The former business model provides companies with greater efficiency through lower costs. Main determinants of cost decrease include existing communications between sellers and buyers, transparency at all stages of supply chains, opportunistic behavior and accelerating sells due to personal interactions. Shifting focus to customer also allow companies offering such configurations and sets of products that increase perceived value for customers. This can be reached through after-sales support, complements, offline services, products that do not directly connected with main product and products from other suppliers. One more important advantage of consumercentric business model lies in creating a pool of loyal customers who make systematic pur- 


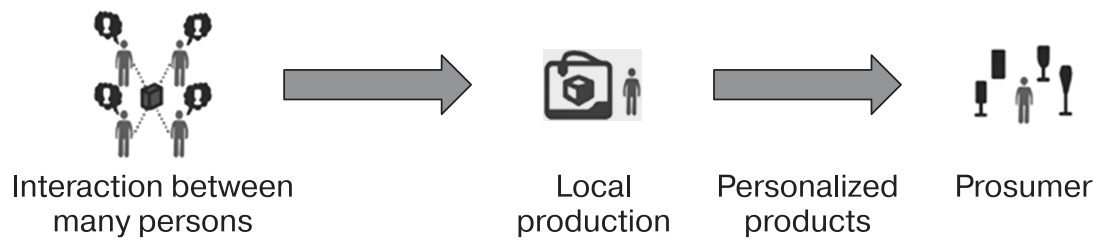

Fig. 1. Involvement of consumer in product development

S o u r e: [Chen et al., 2015].

chases. This is achieved by customized products, development of loyalty programs and products with friendly-user design. Moreover, technologies of digital manufacturing make possible for companies to update their products without the restrictions imposed by technologies or methods of production.

Both researchers and practitioners notice that one of the most important sources of value within consumer-centric business model is opportunity to establish collaboration between designers and developers [Kelly, 2015; Bogers, Hadar, Bilberg, 2016; Rayna, Striukova, 2016]. In [Chen et al., 2015; Bogers, Hadar, Bilberg, 2016] authors claim that $3 \mathrm{D}$ printing can further the principle of co-production between producers and users resulting in value creation for final consumers (fig.1). Besides, it is important to note that the value of co-created products is much higher comparing with mass-produced item [Rayna, Striukova, 2016]. Researchers have noted that in particular cases consumer can carry out the role of designer or he can create a community for discussing design and services concerning 3D printing. Thus, any consumer can become a part of value network. In this, active participation in the creation process has an impact on customer itself: he becomes more important element in value network and can take part in development of larger number of products [Rayna, Striukova, 2016].

Besides, digital manufacturing technologies allow to solve real-world problem concerning designers-developers' collaboration - reduce technological and organizational barriers that prevent such collabora- tion. The solution lies in creation of virtual environment for communication based on technological platform [The third..., 2012]. In other words, digital manufacturing leads to realization of crowd-source approach within manufacturing companies. Moreover, implementation of particular technologies of digital manufacturing can facilitate crowdsourcing usage in product development [Calia, Guerrini, Moura, 2007].

To sum up, traditional manufacturercentric business models have begun to give way to consumer-centric business models. Increasing number of technological changes within manufacturing sector companies had the effect of reducing the number of opportunities to add value through offering little change in products. That is why, far-sighted manufacturers seek to find alternative ways of creating and maintaining value. Manufacturing companies are forced to rethink who and how creates value and who profit. Technologies of digital manufacturing contribute to consumers' involvement into value creation process, reduce the distance between producers and consumers and encourage them to build close relationships.

\section{Changes in marketing activity of manufacturing companies}

The transition from the manufacturer-centric logic to consumer-centric logic has two important implications. On the one hand, it's suggested that consumer is involved into value creation process, and the result of this co-creation will be effective for both parties, on the other hand, changes in the company's business model also have 
a profound impact on the company per se by modifying its strategic and operating activities, in particular, marketing. Creating product-service systems, building a more trusting and close relationships with consumers, consumer involvement in product development and the creation of economically profitable and personalized products are major changes occurring in marketing activities of companies under implementation of digital manufacturing.

Creating product-service systems (PSS). Over the past few years manufacturing companies have started to pay special attention to providing services thus becoming suppliers of complex solutions instead of being just manufacturers [The third..., 2012; Hagel et al., 2015; Lerch, Gotsch, 2015]. Focus shifts from selling a product to making an offer that includes a product and support services specific for that product [Vandermerwe, Rada, 1988; Wise, Baumgartner, 1999; Baines et al., 2009]. Services within such offer range from traditional such as maintain, repair and training to those services that are best designed for each particular client [Mathieu, 2001; Oliva, Kallenberg, 2003; Lay, 2014]. Typically, enhanced services constitute PSS that can be defined as a set of tangible product and intangible customized services [Goedkoop et al., 1999; Tukker, Tischner, 2006]. Implementation of PSS concept by manufacturing companies becomes possible due to introduction of digital manufacturing concept.

PSS includes three components: tangible products, intangible services and information and communications technology (ICT). Namely digital component of PSS lies in the process of creating smart and independent operational systems that, on the one hand, ensure high degree of automation and create opportunities for optimization of operating activity while simultaneously reducing costs; and on the other hand - meet the individual needs of clients. Besides, integration of ICT systems into products provides new opportunities for offering innovative services [Lerch, Gotsch, 2015]. For instance, in contrast to traditional services that are characterized by inseparability, digital services can be provided regardless of location of both producer and consumer. In addition, digital component of PSS allows manufacturers to simplify, speed-up and optimize operating activity and also create new ways of communication with customers [Lerch, Gotsch, 2015].

Generally, providing complex solutions based on digital technologies can influence not only one certain company, but also the whole industry. In particular, implementation of PSS concept in practice is due to collaboration of manufacturing company and suppliers of necessary electronic equipment and software. In this, PSS allow manufacturers to build close relationships with their customers. Even though network of manufacturing company is rather large and complicated, namely this network provides opportunity to produce customer-centric solutions that not only overcome clients' problems, but also creates value for them. Ultimately, utilizing digital technologies for PSS creation can change existing market structures.

Building and development of relationships with customers. Along with implementation of digital technologies in manufacturing companies, relationships between companies and their customers are also changing. Producers seek to get closer to their clients. Recent study of digital technologies implementation conducted by PricewaterhouseCoopers proposes six ways to build close and trusted relationships with customers: (1) basing product/service development on customer specification, (2) innovating on customer service, (3) using data analytics to meet customer requirements and improve operational performance, (4) customizing products all the way down to a lot size of 1, (5) building a customer-focused supply chain, (6) driving customer-centric marketing and channel access.

Building strong relationships with clients through involving them in product cocreation and providing them a possibility to create customized products - is the one of the ways to build connections with custom-

RMJ 15 (4): 537-552 (2017) 
ers and DM technologies play crucial role in this process. New technologies such as 3D printing provide companies with new avenues for cooperation with customers and make producers closer to them. In future, this allow companies to increase level of product customization. Most companies who participated in the study are looking forward to enhancing their product offering through implementation of digital component into both existing and new products. In this, opportunities created by digital technologies not only allow manufacturing companies to be flexible and response to clients' needs quickly, but also allow them to be proactive regarding consumers' claims.

Investigation by $\mathrm{PwC}$ also showed that companies are ready to use big data in order to improve quality service and respond quickly and effectively to emerging challenges [Geissbauer, Vedso, Schrauf, 2016]. Approximately three quarter of companies $(72 \%)$ expect that data analytics will significantly improve their relations with customers and customer intelligence along the product life cycle. Deeper integration of data between producers and customers provides new opportunities for collaboration. Intelligent use of these data allows B2B companies to increase their efficiency or help their clients in value-chain planning [O'Halloran, Kvochko, 2015]. Companies understand the potential benefits that big data can bring. Results of $\mathrm{PwC}$ investigation proves this statement: over a third of surveyed companies $(38 \%)$ plan to hire external companies in order to analyze big data generated while their operation activity.

Changes in the process of developing new products. Companies that implement the concept of digital manufacturing increase their chances to create successful market products. The process of developing new product consists of several stages - concept development, analysis of its feasibility, creation of design layout, prototype, and pilot, and then mass production [Takeuchi, Nonaka, 1986]. The launch of new products is important and risky process for companies. High risks asso- ciated with the inability to accurately predict market reaction to the release of a new and especially innovative products [Khajavi et al., 2015]. In addition, the development of new products is quite costly both from time and financial investment perspective. Taking into account the fact that according to various studies, the level of the failed launch of products varies in the range from $33 \%$ to $90 \%$, the company is interested in reducing the time-to-market cycle, development costs, improving the quality of the manufactured goods and flexibility of product creation process [Cankurtaran, Langerak, Griffin, 2013; Khajavi et al., 2015].

The use of DM technologies, especially additive manufacturing can solve many of mentioned above issues. For example, if engineers have a computer model of the product they can create it or its parts using only additive manufacturing. Rapid prototyping allows technical specialists to check performance and compliance of the model with the requirements and expectations of the customers in the shortest possible time [Gibson, Rosen, Stucker, 2010]. In addition, the absence of production constraints allows designers and constructors to develop and test new forms and new materials of new products [LaMonica, 2013; Chen et al., 2015]. For instance, General Electric company uses additive technology to print fuel nozzles. According to the company, it helps her firstly to reduce the number of required metal, as there is no risk of the defect existence; secondly, to reduce the cost of the finished product, because the new aircraft detail is easier and save aviation fuel; thirdly, to simplify the production process, as in the traditional manufacturing of nozzles 20 separate parts should be welding, which is a time consuming process, while additive technology allows company to produce an entire product immediately [LaMonica, 2013].

Another aspect associated with the creation of successful market products is the production of profitable but at the same time personalized products. It requires data 
analysis of consumer preferences and reveals what company needs to produce in accordance with individual customer's requirements, and what components of the product should be personalized. Computer software will be relevant for the task of data collection and analyses. At the production stage, to maintain an acceptable level of costs, company can use dynamic programmed robotic systems and switch between production of different product models with minimal cost [Gandhi, Magar, Roberts, 2014].

\section{Conclusion}

This study attempts to facilitate discussion of digital transformation of industry. Systematizing and drawing examples of digital implementations we have advocated the idea that digitalization is not an isolated issue of new technologies based on data flows, HCI and automatization. Importantly that digitalization brings new view on business model as well as reshapes all important business processes. With that new sources of value added together with additional risks are brought to companies' activities.

In our paper we have placed a stress on the issue that implementation of digital manufacturing creates new opportunities for companies from a marketing point of view. Changes in consumer behavior - how consumers perceive and use products forces companies to rethink factors that determine product value and way of its delivery. Companies start to rethink physical products as services and produce personalized offers for their customers. At the same time DM technologies increase companies' profitability by reducing the cost of raw materials and energy and optimize the production process. Generally, it leads to improvement in competitiveness position because company can create and bring to the market successful products in a short time and at an attractive price.

The following important findings are to be highlighted when it comes to integrated digitalization of manufacturing companies.
1) Technologies appear to overtake employees' qualification and skills. This phenomenon has ambivalent implication. Positive side of the rapidly developing technologies addresses incentives for HR development and sources of productivity growth. Meanwhile, significant risks of HR gaps might deprive companies to be better off wen digitalization is extensively implemented.

2) Companies become a substantially transparent entity for all stakeholders especially for customers and rivals. This transformation outcome may again have conflicting and sometimes contradictory impact. Customers act as active co-creators demanding high degree of customization even on very early stages of product development. At the same time, rivals take advantage of information dissemination cutting costs and increasing competition tensions.

3) Physical boundaries of business starting to disappear. Companies and manufacturing processes network and collaborate for short-term to fulfill certain objectives and tasks and disconnect afterwards. On the one hand, this agile behavior perfectly matches contemporary conditions, on the other; it might create distortions due to "blurred" responsibility to different beneficiaries of business, such as investors, debtors.

Overall, the changes in companies' business model and companies' marketing activity are linked closely. Smart goods that created because of co-creation process between companies and consumers and combine characteristics services are consequences of manufacturing digitalization. The idea that a company can create value only through the production and sale of goods, is becoming obsolete. Changes in the nature of the product entail changes in processes of value creation. New market realities make array of data, interactions, collaborations with customers and its response, constant training basis of the value. All of this can lay the foundation of totally new business models. 


\section{REFERENCES}

Abrell T., Pihlajamaa M., Kanto L., vom Brocke J., Uebernickel F. 2016. The role of users and customers in digital innovation: Insights from B2B manufacturing firms. Information \& Management 53 (3): 324-335.

Afuah A. 2015. Business Model Innovation: Concepts, Analysis, and Cases. Routledge: N.Y.

Amit R., Zott C. 2001. Value creation in e-business. Strategic Management Journal 22 (6-7): 493-520.

Baines T.S., Lightfoot H.W., Benedettini O., Kay J.M. 2009. The servitization of manufacturing: A review of literature and reflection on future challenges. Journal of Manufacturing Technology Management 20 (5): 547-567.

Baur C., Wee D. 2015. Manufacturing's Next Act. [Electronic resource]. http://www. mckinsey.com/business-functions/operations/our-insights/manufacturings-nextact (accessed: 03.05.2016).

Bloem J., van Doorn M., Duivestein S., Excoffier D., Maas R., van Ommeren E. 2014. The Fourth Industrial Revolution. Things to Tighten the Link Between IT and OT. [Electronic resource]. http://www.fr.sogeti. com/globalassets/global/downloads/reports/vint-research-3-the-fourth-industrial-revolution (accessed: 03.05.2016).

Bogers M., Hadar R., Bilberg A. 2016. Additive manufacturing for consumer-centric business models: Implications for supply chains in consumer goods manufacturing. Technological Forecasting and Social Change 102: 225-239.

Boosting Visibility, Agility and Profits with Digital Manufacturing. 2015. Cisco. [Electronic resource]. http://cisco.com (accessed: 03.05.2016).

Geissbauer R., Vedso J., Schrauf S. 2016. Industry 4.0: Building the Digital Enterprise. PricewaterhouseCoopers Survey. [Electronic resource]. http://www.pwc.com/gx/en/ industries/industries-4.0/landing-page/industry-4.0-building-your-digital-enterpriseapril-2016.pdf (accessed: 03.05.2016).

Calia R.C., Guerrini F.M., Moura G.L. 2007. Innovation networks: From technological development to business model reconfiguration. Technovation 27 (8): 426-432.

Cankurtaran P., Langerak F., Griffin A. 2013. Consequences of new product development speed: A meta-analysis. Journal of Product Innovation Management 30 (3): 465-486.

Chen D., Heyer S., Ibbotson S., Salonitis K., Steingrímsson J.G., Thiedee S. 2015. Direct digital manufacturing: Definition, evolution, and sustainability implications. Journal of Cleaner Production 107: 615-625.

Chesbrough H. 2010. Business model innovation: Opportunities and barriers. Long Range Planning 43 (2-3): 354-363.

Chryssolouris G. et al. 2009. Digital manufacturing: History, perspectives, and outlook. Proceedings of the Institution of Mechanical Engineers, Part B: Journal of Engineering Manufacture 223 (5): 451-462.

Dalton-Taggart R. 2005. The move to digital manufacturing. Tooling \& Production (April): 30-32.

Digital Manufacturing "Enabling Lean for More Flexible Manufacturing”. 2011. A CIMdata Report (August). [Electronic resource]. https://www.plm.automation.siemens.com/en us/Images/Siemens-PLMFlexible-Mfg-CIMdata_WP_20110830_tcm 1023-133968.pdf (accessed: 19.09.2016).

Digital Manufacturing. 2015a. Siemens Totally Integrated Automation, The VAULT website (August, 18). [Electronic resource]. http://www.totallyintegratedautomation. com/2015/08/digital-manufacturing/ (accessed: 19.09.2016).

Digital Manufacturing. A Holistic Approach to the Complete Product Lifecycle. 2015b. Automotive Manufacturing Forum. Siemens Industry. [Electronic resource]. http:// www.industry.usa.siemens.com/automation/us/en/formsdocs/Documents/AMAR UTO1_0715_Digital_Manufacturing.pdf (accessed: 19.09.2016).

Digitalization. Germany 2014 Digitalization. 2015. Siemens Customer Survey. Result Report. [Electronic resource]. http://www. siemens.com/digitalization/public/pdf/ 20151119_SI_Kundenbefragung_Germany_EN.pdf (accessed: 19.09.2016). 
Digitalization - Trends and Solutions for a More Competitive Brazil 2015. 2015. Siemens Customer Survey. Result Report. [Electronic resource]. https://m.siemens. com/en/about/core-topics/digitalization/ media/pdf/12684_SI_Kundenbefragung_ Brasilien_EN.pdf (accessed: 19.09.2016).

Gandhi A., Magar C., Roberts R. 2014. How technology can drive the next wave of mass customization. Business Technology Office McKinsey \& Company; 1-8.

Gibson I., Rosen D., Stucker B. 2010. Additive Manufacturing Technologies. Springer: N.Y.

Goedkoop M.J., van Halen C.J.G., te Riele H.R.M., Rommens P.J.M. 1999. Product Service Systems: Ecological and Economic Basics. Dutch Ministries of Environment (VROM): Hague, Netherlands (accessed: 30.09.2014).

Grieves M. 2005. Product Lifecycle Management: Driving the Next Generation of Lean Thinking. McGraw-Hill: N.Y.

Grieves M. 2015. Can the Digital Twin Transform Manufacturing. World Economic Forum. [Electronic resource]. https://www. weforum.org/agenda/2015/10/can-thedigital-twin-transform-manufacturing (accessed: 03.05.2016).

Hagel III J., Brown J.S., Kulasooriya D., Giffi C., Chen M. 2015. The Future of Manufacturing. Making Things in a Changing World. Deloitte University Press. [Electronic resource]. http://www2.deloitte.com/content/dam/Deloitte/za/Documents/manufacturing/ZA_Future_of_Manufacturing_ 2015.pdf (accessed: 19.09.2016).

Hu S.J. 2013. Evolving paradigms of manufacturing: From mass production to mass customization and personalization. Procedia CIRP 7: 3-8.

Johnson M. W., Christensen C. M., Kagermann H. 2008. Reinventing your business model. Harvard Business Review 86 (12): 57-68.

Kelly R. 2015. The Digital-Manufacturing Revolution: How It Could Unfold. McKinsey \& Company. [Electronic resource]. http://www.mckinsey.com/business-func- tions/operations/our-insights/the-digitalmanufacturing-revolution-how-it-couldunfold (accessed: 03.05.2016).

Khajavi S.H., Partanen J., Holmström J., Tuomi J. 2015. Risk reduction in new product launch: A hybrid approach combining direct digital and tool-based manufacturing. Computers in Industry 74: 29-42.

Kuehn W. 2006. Digital Factory: Integration of Simulation from Product and Production Planning towards Operative control. ECMS: 20th European Conference on modelling and simulation, May 28-31. Bonn, St.Augustin.

LaMonica M. 2013. Additive manufacturing. GE, the world's largest manufacturer, is on the verge of using 3-D printing to make jet parts. MIT Technology Review. [Electronic resource]. https://www.technologyreview. $\mathrm{com} / \mathrm{s} / 513716 /$ additive-manufacturing (accessed: 03.05.2016).

Lay G. (ed.). 2014. Servitization in Industry. Springer: N.Y.

Lerch C., Gotsch M. 2015. Digitalized product-service systems in manufacturing firms: A case study analysis. Research-Technology Management 58 (5): 45-52.

Macaulay J., O'Connell K., Namboodri C., Delaney K. 2015. The Digital Manufacturer. Resolving the Service Dilemma. Cisco. [Electronic resource]. http://www.cisco.com/c/ $\mathrm{dam} /$ en_us/solutions/industries/manufacturing/thought-leadership-wp.pdf (accessed: 03.05.2016).

Mathieu V. 2001. Product services: From a service supporting the product to a service supporting the client. Journal of Business \& Industrial Marketing 16 (1): 39-61.

Miller E., MacKrell J. 2006. Digital Manufacturing: Moving the Design into Production. CIMdata.

Namboodri C. 2015. Digital Manufacturing: Transforming Your Business Model. Cisco. [Electronic resource]. http://blogs.cisco. $\mathrm{com} /$ manufacturing/digital-mfg-transforming-business (accessed: 03.05.2016).

O'Halloran D., Kvochko E. 2015. Industrial Internet of Things: Unleashing the Poten- 
tial of Connected Products and Services. World Economic Forum. [Electronic resource]. http://www3.weforum.org/docs/ WEFUSA_IndustrialInternet_Report2015. pdf (accessed: 03.05.2016).

Oliva R., Kallenberg R. 2003. Managing the transition from products to services. International Journal of Service Industry Management 14 (2): 160-172.

Rashid B. 2017. Digital transformation and innovation in today's business world. Forbes (July, 13). [Electronic resource]. https:// www.forbes.com/sites/brianrashid/2017/ 06/13/digital-transformation-and-innovation-in-todays-business-world/\#748d927 04905 (accessed: 09.09.2017).

Rayna T., Striukova L. 2016. From rapid prototyping to home fabrication: How 3D printing is changing business model innovation. Technological Forecasting and Social Change 102: 214-224.

Robinson A. 2015. Industry 4.0: Powered by the Internet of Things \& Digital Manufacturing. Cerasis. [Electronic resource]. http:// cerasis.com/2015/07/15/industry-4-0/ (accessed: 03.05.2016).

Gerbert P., Lorenz M., Rüßmann M., Waldner M, Justus J., Engel P., Harnisch M. 2015. Industry 4.0-The Future of Productivity and Growth in Manufacturing Industries. Boston Consulting Group: MA.

Schwab K. 2016. The Fourth Industrial Revolution: What It Means, How to Respond. World Economic Forum. [Electronic resource]. https://www.weforum.org/agen$\mathrm{da} / 2016 / 01 /$ the-fourth-industrial-revolution-what-it-means-and-how-to-respond (accessed: 03.05.2016).

Spelman M. et al. 2016. Digital Transformation of Industries: Automotive Industry. World Economic Forum. [Electronic resource]. http://reports.weforum.org/digital-transformation/automotive/ (accessed: 03.05.2016).
Takeuchi H., Nonaka I. 1986. The new product development game. Harvard Business Review 64 (1): 137-146.

The Digital Transformation of Business. 2015. A Harvard Business Review Analytic Services Report. [Electronic resource]. https:// msinservices.blob.core.windows.net/digitaltransformation/Digital-Transformationof-Business-Harvard-Business-Review.pdf (accessed: 03.05.2016).

The third industrial revolution. 2012. The Economist. [Electronic resource]. http:// www.economist.com/node/21552901 (accessed: 03.05.2016).

Tukker A., Tischner U. 2006. Product-services as a research field: Past, present and future. Reflections from a decade of research. Journal of Cleaner Production 14 (17): 1552-1556.

Vandermerwe S., Rada J. 1988. Servitization of business: Adding value by adding services. European Management Journal 6 (4): 314-324.

Wee D., Kelly R., Cattell J., Breunig M. 2015. Industry 4.0 How to Navigate Digitization of the Manufacturing Sector. McKinsey \& Company. [Electronic resource]. https://www. mckinsey.de/sites/mck_files/files/mck_industry_40_report.pdf (accessed: 03.05.2016).

Westkämper E. 2007. Strategic development of factories under the influence of emergent technologies. CIRP Annals-Manufacturing Technology (1): 419-422.

Wise R., Baumgartner P. 1999. Go downstream: The new profit imperative in manufacturing. Harvard Business Review $\mathbf{7 7}$ (5): 133-141.

Zhou Z., Xie S.S., Chen D. 2011. Fundamentals of Digital Manufacturing Science. Springer: N.Y.

Zott C., Amit R., Massa L. 2011. The business model: Recent developments and future research. Journal of Management 37 (4): 1019-1042.

Initial Submission: December 5, 2017 Final Version Accepted: December 18, 2017 


\section{Цифровое производство: новые вызовь для ларкетинга и бизнес-лоделей*}

\section{А.О.Давий}

Национальный исследовательский университет "Высшая школа эконолики» - Санкт-

Петербург, Россия

E-mail: adaviy@hse.ru

\section{С. Н.Паклина}

Национальный исследовательский университет «Высшал школа эконолики» - Перль, Россия

E-mail: snpaklina@yandex.ru

\section{А.С. Прокофьева}

ГК «Галактика», Москва, Россия

E-mail: Aliya@galaktika.space

Статья посвящена определению роли «цифрового производства» (digital manufacturing) в изменении маркетинговой деятельности производственных компаний с позиции системы управления бизнесом. В статье сформулировано и концептуализировано определение понятия «цифровое производство». В основе методологии теоретического исследования лежит методология компании Deloitte, которая предлагает оценивать изменения, происходящие на производстве, с позиции создания ценности. Основными параметрами, которые анализируются в рамках данной методологии, являются потребитель, продукт, экономика производства и цепочки создания ценности. На основе проведенного анализа было определено, что внедрение и реализация на производственных предприятиях цифрового производства неминуемо влекут за собой изменения в бизнес-модели компании и ее маркетинговой деятельности. Отношения с потребителями и новые возможности при разработке и создании продукта - основные драйверы данного процесса. Взаимодействие с конечным покупателем без посредников, вовлечение его в процессы разработки новых продуктов, новые технические возможности по созданию персонализированной продукции, нередко объединяющей в себе черты товара и услуги, - основные изменения в маркетинговой деятельности, вызванные внедрением цифрового производства на предприятия. Ключевые слова: цифровое производство, маркетинг, бизнес-модель.

JEL: M31.

https://doi.org/10.21638/11701/spbu18.2017.408

Статья поступила в редакцию 5 декабря 2017 г. Принята к публикации 18 декабря 2017 г.

\footnotetext{
* Исследование проведено в ходе проведения работ в рамках Программы «Научный фонд Национального исследовательского университета «Высшая школа экономики» (НИУ ВШЭ)» в 2016-2017 гг. (проект 1601-0079) в рамках государственной поддержки ведущих университетов Российской Федерации «5-100» .
} 